\title{
Soybean and wheat response to lime in no-till Argentinean mollisols
}

\author{
Pablo A. Barbieri a,b,*, Hernán E. Echeverría ${ }^{a, c}$, Hernán R. Sainz Rozas ${ }^{a, b, c}$, \\ Juan P. Martínez ${ }^{\mathrm{c}}$ \\ a EEA-INTA Balcarce, Argentina \\ ${ }^{\mathrm{b}}$ CONICET, Argentina \\ ${ }^{\mathrm{c}}$ Facultad Ciencias Agrarias, UNMP, Argentina
}

\section{A R T I C LE IN F O}

\section{Article history:}

Received 23 May 2014

Received in revised form 25 March 2015

Accepted 27 March 2015

\section{Keywords:}

Argentina

Base saturation

Grain yield

Lime soil $\mathrm{pH}$

Soil $\mathrm{Ca}^{+2}$ content

Soybean

Wheat

\begin{abstract}
A B S T R A C T
Crop production in Argentina has significantly increased over the past few years; this increase was consequence of better management practices which included $\mathrm{P}$ and $\mathrm{N}$ fertilization and, occasionally, $\mathrm{S}$ fertilization. Commonly used rates, however, are not sufficient to balance nutrients export in grain crops. This situation is particularly negative for meso-nutrients $\left(\mathrm{Ca}^{+2}\right.$ and $\left.\mathrm{Mg}^{+2}\right)$ because they are not normally applied by farmers. The objective of this study was to determine the effect of lime over four years period on soybean, one year period on wheat and on a one year double cropped wheat/soybean combination on no-till. The experimental design was a randomized complete blocks design with three replications and two combinations of lime (with and without). Results showed that lime application significantly increased soil $\mathrm{pH}$, exchangeable $\mathrm{Ca}^{+2}$ content, and therefore, base saturation and $\mathrm{Ca}^{+2}$ saturation in cation exchangeable capacity (CEC). As average growing seasons, the relative increments due to lime application were $8,22,18$, and $20 \%$ for $\mathrm{pH}$, soil exchangeable $\mathrm{Ca}^{+2}$ content, base saturation and $\mathrm{Ca}^{+2}$ saturation in CEC, respectively. Results showed that soil bulk density and penetration resistance were not affected by lime application. Soil structure stability was significantly affected by lime application. Wheat grain yield was not affected by lime, but soybean grain yield was significantly increased by lime (7\% average across year). Cumulative grain yield was significantly increased by lime application indicating that the benefits of liming were cumulative over time $\left(27,556 \mathrm{vs} 28,629 \mathrm{~kg} \mathrm{ha}^{-1}\right.$ for lime and no lime, respectively). Increments in relative grain yield were not associated with soil $\mathrm{pH}$ in both crops; however, significant relationships were determined between relative soybean grain yield and soil $\mathrm{Ca}^{+2}$ content, base saturation and $\mathrm{Ca}^{+2}$ content in CEC. A soil $\mathrm{Ca}^{+2}$ critical concentration of $12.4 \mathrm{meq} 100 \mathrm{~g}^{-1}$ was determined to obtain $95 \%$ of relative soybean grain yield. The study concluded that soil $\mathrm{Ca}^{+2}$ content would limit soybean grain yield as a consequence of cation unbalance in intensive agriculture soil.
\end{abstract}

(c) 2015 Elsevier B.V. All rights reserved.

\section{Introduction}

The southeast of the humid Argentine Pampas is one of the regions in the world with superior conditions for grain crop production (Martínez et al., 2013), due to temperate climate, adequate rainfall and a large proportion of soils belonging to the great group Argiudolls, with high productivity. Because of this, the region has a high potential for winter and summer crop production. Most of the agricultural soils of this region belong to Typic Argiudoll and and Petrocalcic Paleudoll which present discontinuous layers of petrocalcic horizon below $0.8 \mathrm{~m}$ and

\footnotetext{
* Corresponding author at: EEA INTA Balcarce, Ruta Nac. $226 \mathrm{~km} \mathrm{73.5,} 7620$ Balcarce, Buenos Aires, Argentina. Tel.: +54 2266439140.

E-mail address: barbieri.pablo@inta.gob.ar (P.A. Barbieri).
}

greater clay contents at sub-surface layers than Typic Argiudolls (USDA Taxonomy). These soils have organic matter content ranging from 3 to $6 \%$, low available $\mathrm{P}(6-10 \mathrm{ppm}$ Bray-1-P) and $\mathrm{pH}$ values from moderately acidic (5.5-6.4) (Sainz Rozas et al., 2011, 2012).

Soil acidity can affect plant growth directly and indirectly by affecting availability of plant nutrients, levels of phytotoxic elements, microbial activity and other soil properties (Brady and Weill, 1999). Soils may become acidic in the long term as a result of several natural processes (leaching of basic cations). In the short term, however, soil acidity develops mainly due to removal of bases (e.g., Ca, Mg, K,) by harvested crops (Bouman et al., 1995), coupled with the residual acid that is left in the soil from $\mathrm{N}$ and $\mathrm{P}$ fertilization (Tarkalson et al., 2006). Soil acidity is a serious limitation for crop production in many regions of the world. Soil acidity problems are commonly corrected by application of limestone. However, the rate of lime to be applied is calculated 


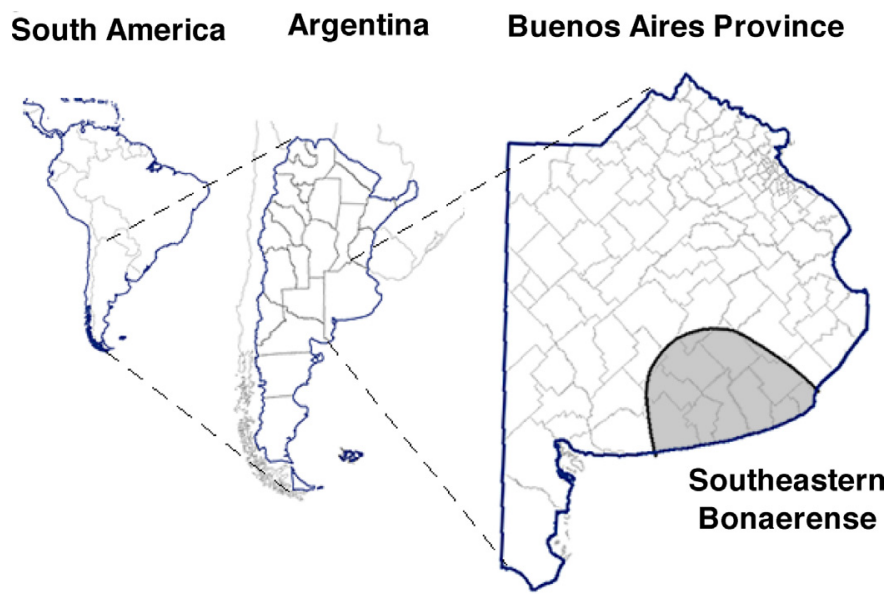

Fig. 1. Map of South America indicating Argentina, Buenos Aires province and the shadow area comprises South-Eastern Buenos Aires.

by different methods (Shoemaker-McLean-Pratt, Sikora, and Mehlich buffer $\mathrm{pH}$, and titratable acidity). The common practice for liming no-tillage consists of applying lime to soil surface without incorporation into the soil. Surface applied lime is effective to improve soil $\mathrm{pH}$ and increased crop grain yields (Caires et al., 2005, 2010; Godsey et al., 2007; Joris et al., 2013; Fageria et al., 2013, 2014).

In southeast of the humid Argentine Pampas region (Fig. 1), wheat and soybean are the most important winter and summer crops, respectively. However, over the last 30 years, the region has been intensively cultivated to soybean (Glycine Max. L. Merr.). This has led to serious deterioration of soil physical, biological and chemical properties. In this region, crop production has been significantly increased in the last years as consequence of better management practices which included $\mathrm{P}$ and $\mathrm{N}$ fertilization and, occasionally, $\mathrm{S}$ fertilization. On the other hand, a reduction in soil organic matter (Sainz Rozas et al., 2011) and the large area under no-tillage has increased markedly the $\mathrm{N}$ deficiencies and crop response to this nutrient (Sainz Rozas et al., 2008; Velasco et al., 2012; Barbieri et al., 2012). Therefore, applied $\mathrm{N}$ rate to crops has been increased contributing to progressive soils acidification (Sainz Rozas et al., 2011). However, until the moment, mesonutrient fertilizers $\left(\mathrm{Ca}^{+2}\right.$ and $\mathrm{Mg}^{+2}$ ) were not used by farmers in field crops. The major effect of acidification is a depletion of exchangeable $\mathrm{Ca}^{+2}$ and $\mathrm{Mg}^{+2}$ (Bouman et al., 1995). Recently, a survey on pristine and agricultural soils $(0-20 \mathrm{~cm}$ depth) in Pampas regions (Sainz Rozas et al., 2013) determined the reduction in exchangeable $\mathrm{Ca}^{+2}$ and $\mathrm{Mg}^{+2}$ content of $12 \%$ and $18 \%$, respectively as consequence of agriculture. However, average soil $\mathrm{Mg}$ content was in the range of high and very high availability $(254 \mathrm{ppm})$. Exchangeable $\mathrm{Ca}^{+2}$ in some of the areas surveyed was between 600 and $1200 \mathrm{mg} \mathrm{kg}^{-1}$ in which positive response to lime application were determined in soybean and alfalfa (Gambaudo and Fontanetto, 2011; Vázquez et al., 2010; Vázquez, 2011). This exchangeable $\mathrm{Ca}^{+2}$ could be limiting in soils with high cation exchangeable capacity (CEC) as those of southeast of Buenos Aires province because $\mathrm{Ca}^{+2}$ saturation would be lower than $50 \%$ (Havlin et al., 2005) in the most of situations. On the other hand, $\mathrm{Ca}^{+2}$ and $\mathrm{Mg}^{+2}$ together with organic matter are cementing agents involved in soil aggregate process (Brady and Weill, 1999). Therefore, liming

Table 1

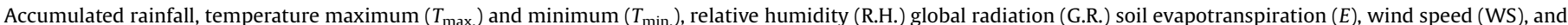
heliophany for experimental site from 1984-2013.

\begin{tabular}{|c|c|c|c|c|c|c|c|c|}
\hline Month & Rainfall (mm) & $T_{\text {max. }}\left({ }^{\circ} \mathrm{C}\right)$ & $T_{\text {min. }}\left({ }^{\circ} \mathrm{C}\right)$ & R.H. (\%) & G.R. $\left(\mathrm{Mj} \mathrm{m}^{-2}\right)$ & $E(\mathrm{~mm})$ & WS $\left(\mathrm{km} \mathrm{h}^{-1}\right)$ & $H(\mathrm{~h})$ \\
\hline Jan & 109.3 & 27.8 & 14.2 & 70 & 22.6 & 141.0 & 6.9 & 8.77 \\
\hline Feb & 83.5 & 26.5 & 13.8 & 74 & 19.9 & 108.5 & 7.0 & 8.17 \\
\hline March & 92.1 & 24.3 & 12.4 & 77 & 15.2 & 82.1 & 6.5 & 6.77 \\
\hline April & 75.6 & 20.5 & 9.0 & 78 & 11.0 & 46.0 & 6.1 & 5.77 \\
\hline May & 56.9 & 16.3 & 6.2 & 81 & 7.3 & 23.1 & 6.1 & 4.44 \\
\hline June & 49.6 & 13.2 & 3.9 & 83 & 5.9 & 15.3 & 6.6 & 3.96 \\
\hline July & 48.8 & 12.3 & 3.1 & 83 & 6.4 & 17.2 & 7.1 & 3.96 \\
\hline Aug & 54.6 & 14.4 & 4.1 & 80 & 8.8 & 31.7 & 7.1 & 4.71 \\
\hline Sept & 62.6 & 16.2 & 5.1 & 78 & 12.4 & 49.7 & 7.7 & 5.54 \\
\hline Oct & 88.2 & 19.4 & 7.8 & 77 & 16.3 & 77.3 & 7.5 & 6.43 \\
\hline Nov & 98.7 & 22.8 & 10.1 & 73 & 20.4 & 106.7 & 7.3 & 7.81 \\
\hline Dec & 92.2 & 25.9 & 12.3 & 69.0 & 23.1 & 137.4 & 7.49 & 8.87 \\
\hline Annual & 912 & 19.9 & 8.5 & 76.9 & 14.1 & 835.8 & 6.9 & 6.3 \\
\hline
\end{tabular}

Table 2

Some characteristics of the soil surface (0-20 cm depth) at the initial condition in 2006/07 and 2010/11 growing season.

\begin{tabular}{|c|c|c|c|c|c|c|c|c|c|}
\hline \multicolumn{10}{|l|}{$2006 / 07$} \\
\hline $\mathrm{p}$ & MO & $\mathrm{pH}$ & $\mathrm{Ca}^{+2}$ & $\mathrm{Mg}^{+2}$ & $\mathrm{Na}^{+}$ & $\mathrm{K}^{+}$ & CEC & BS & Ca sat in CEC \\
\hline $\mathrm{mg} \mathrm{kg}^{-1}$ & $\%$ & $\%$ & meq $100 \mathrm{~g}^{-1}$ & meq $100 \mathrm{~g}^{-1}$ & meq $100 \mathrm{~g}^{-1}$ & meq $100 \mathrm{~g}^{-1}$ & meq $100 \mathrm{~g}^{-1}$ & $\%$ & $\%$ \\
\hline 17.0 & 5.9 & 5.7 & 12.6 & 1.6 & 0.22 & 2.0 & 26.9 & 61.2 & 47.0 \\
\hline \multicolumn{10}{|c|}{ No lime $2013 / 14$} \\
\hline $\mathrm{P}$ & MO & $\mathrm{pH}$ & $\mathrm{Ca}^{+2}$ & $\mathrm{Mg}^{+2}$ & $\mathrm{Na}^{+}$ & $\mathrm{K}^{+}$ & CEC & BS & Ca sat in CEC \\
\hline $\mathrm{mg} \mathrm{kg}^{-1}$ & $\%$ & $\%$ & meq $100 \mathrm{~g}^{-1}$ & meq $100 \mathrm{~g}^{-1}$ & meq $100 \mathrm{~g}^{-1}$ & meq $100 \mathrm{~g}^{-1}$ & meq $100 \mathrm{~g}^{-1}$ & $\%$ & $\%$ \\
\hline 44.2 & 5.6 & $5.8 \mathrm{~b}$ & $10.0 \mathrm{~b}$ & $1.5 b^{1}$ & $0.21 \mathrm{a}$ & $2.6 a$ & $26.1 \mathrm{a}$ & $54.4 \mathrm{~b}$ & $38.2 \mathrm{~b}$ \\
\hline \multicolumn{10}{|c|}{ Lime 2013/14 } \\
\hline $\mathrm{P}$ & MO & $\mathrm{pH}$ & $\mathrm{Ca}^{+2}$ & $\mathrm{Mg}^{+2}$ & $\mathrm{Na}^{+}$ & $\mathrm{K}^{+}$ & CEC & BS & Ca sat in CEC \\
\hline $\mathrm{mg} \mathrm{kg}^{-1}$ & $\%$ & $\%$ & meq $100 \mathrm{~g}^{-1}$ & meq $100 \mathrm{~g}^{-1}$ & meq $100 \mathrm{~g}^{-1}$ & meq $100 \mathrm{~g}^{-1}$ & meq $100 \mathrm{~g}^{-1}$ & $\%$ & $\%$ \\
\hline 45.0 & 5.6 & $6.5 a$ & $13.2 \mathrm{a}$ & $2.4 \mathrm{a}$ & $0.20 \mathrm{a}^{1}$ & $2.6 a$ & $25.8 \mathrm{a}$ & $74.3 a$ & $51.2 \mathrm{a}$ \\
\hline
\end{tabular}

Ca, soil calcium content; CEC, cation exchangeable capacity; BS, base saturation; Ca sat in CEC, calcium saturation in cation exchangeable capacity.

1 Means followed by the same letter are not significantly different from each other based on the LSD test. 
would promote the formation of cementing process, exercising soil structuration (Vázquez et al., 2009). Therefore, it is necessary to evaluate if crops sensitive to soil acidity would response to $\mathrm{Ca}^{+2}$ fertilization. The objective of this study was to determine the effect of lime application in a long term field trial under no-till on grain yield and soil properties during six growing seasons (2006/07, 2007/08, 2008/09, 2009/10, 2010/11, and 2013/14) in a crop sequence that included five soybean crops and two wheat crops.
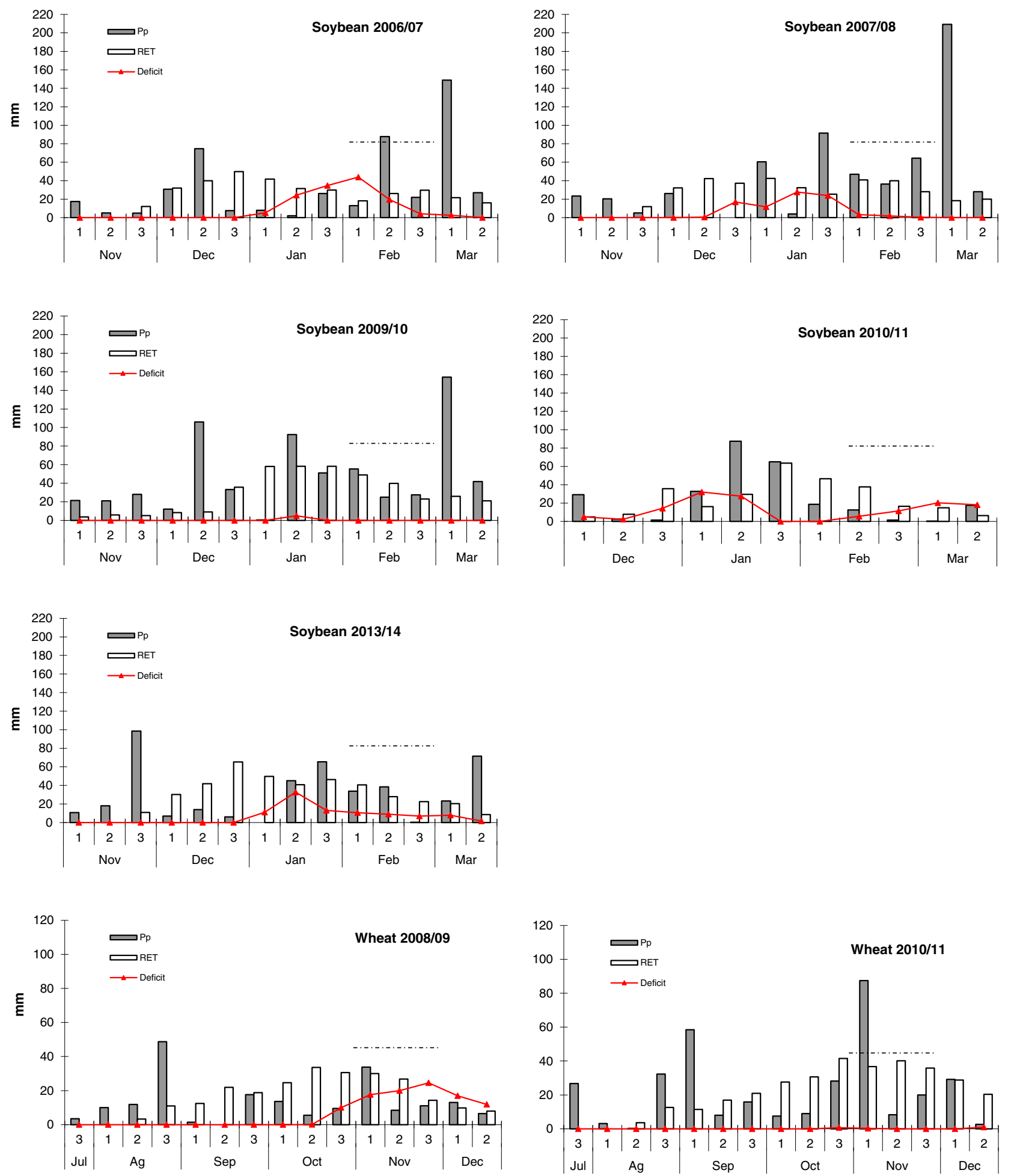

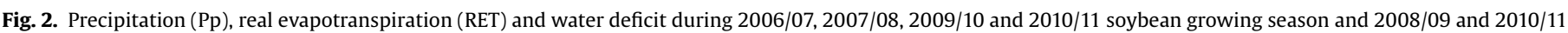
wheat growing season. Dotted line indicates critical period to kernel set.

\section{Materials and method}

The study was performed in a long term field trial under no-till initiated in 2006 and crop sequence was: soybean (Glycine max L. Merr.) (2006/07, 2007/08), wheat (Triticum aestivum L.) (2008/09)soybean (2010/11), wheat/soybean as double crop (2010/11) and soybean (2013-11) and soybean (2013-/14). The experiment was located at the Instituto Nacional de Tecnología Agropecuaria (INTA)
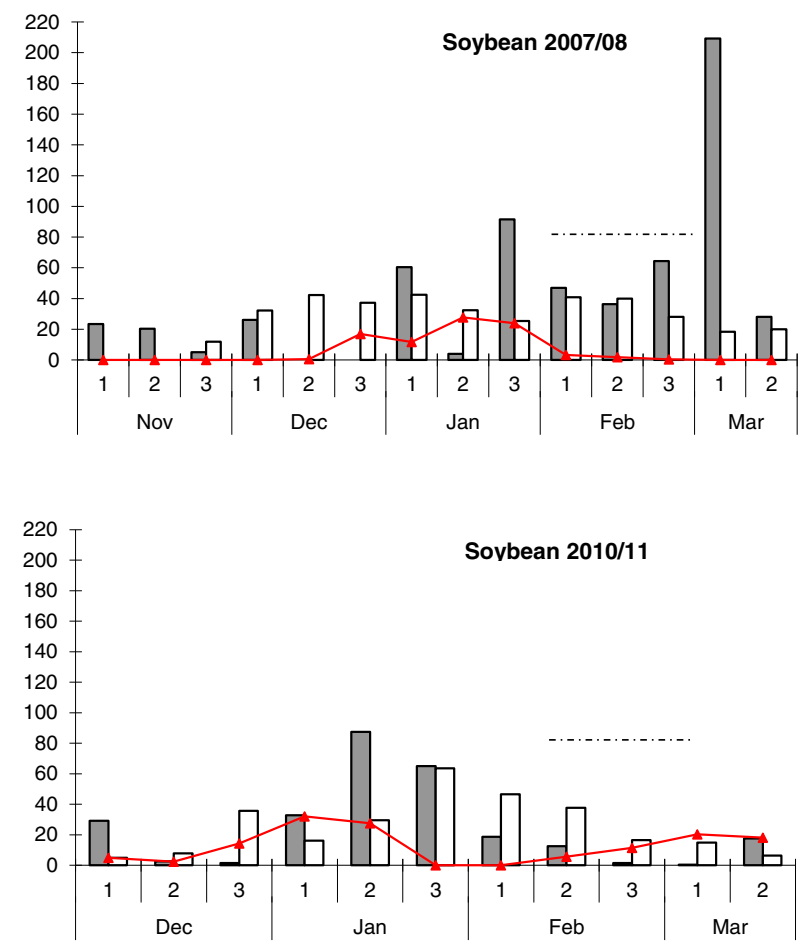
Table 3

Soil $\mathrm{pH}$, soil calcium content, base saturation and calcium saturation in cation exchangeable capacity affected by lime application.

\begin{tabular}{lllll}
\hline & $\mathrm{pH}$ & $\mathrm{Ca}^{+2}$ & $\mathrm{BS}$ & Ca sat in CEC \\
\hline Treatment $(T)$ & 0.0001 & 0.0001 & 0.0001 & 0.0001 \\
Year $(Y)$ & 0.0001 & 0.0001 & 0.8007 & 0.0930 \\
$T \times Y$ & 0.0001 & 0.0003 & 0.0003 & 0.0005 \\
\hline
\end{tabular}

Ca, soil calcium content; BS, base saturation; Ca sat in CEC, calcium saturation in cation exchangeable capacity.

Research Station, Balcarce $\left(37^{\circ} 45^{\prime} \mathrm{S} ; 58^{\circ} 18^{\prime} \mathrm{W} ; 130 \mathrm{~m}\right.$ above sea level) Buenos Aires, Argentina. Average climate data for experimental sites from 1984 to 2013 are shown in the Table 1. The soil was a fine mixed Typic Argiudoll (USDA Taxonomy), with a loam texture at the surface layer (0-25-cm depth), loam to clay-loam at sub-surface layers (25-110-cm depth) and sandy-loam below $110-\mathrm{cm}$ depth (C-horizon). The soil where the experiment was conducted is representative of an area about 2.2 million ha (Fig. 1). Some soil characteristics determined at the beginning of experiment in 2006/07 growing season and the last growing season 2013/14 growing season are presented in Table 2 .

The experimental design was a randomized complete blocks design (RCBD) with three replications and two combinations of lime (with and without). Lime requirements were calculated as $80 \%$ of base saturation in CEC. Lime was applied broadcast on the soil surface by hand only on soybean crops. The rate of lime (dolomite) applied $\left(\mathrm{Ca}^{+2} 24 \%, \mathrm{Mg}^{+2} 9.2 \%\right)$ was $6.2,5.3$, 4.6 $\mathrm{Mg} \mathrm{ha}^{-1}$, and 3.1 $\mathrm{Mg} \mathrm{ha}^{-1}$ in 2006-07, 2007-08, 2009-10, and 2013-14 growing seasons, respectively. Plot size was $75 \mathrm{~m}^{2}$ in size ( $5 \mathrm{~m}$ wide by $15 \mathrm{~m}$ long). At all growing seasons, soil organic matter (Walkley and Black, 1934), P Bray content (Bray and Kurtz, 1945), pH (water 1:2.5), soil Ca concentration and cation exchange capacity (CEC) were measured at $0-20 \mathrm{~cm}$ depth (Chapman, 1965; Schollenberger and Simon, 1945). At the beginning of experiment in 2006/07 growing season, before soybean sowing, exchangeable acidity (Thomas, 1982) and titratable acidity (Peech, 1965) were measured at 0-20 cm depth.

In 2010/11 growing season, soil bulk density (BD) 0-5 and $5-10 \mathrm{~cm}$ depth was determined by the core method (Blake and Hartge, 1986) using a core sampler of $50.0 \mathrm{~mm}$ diameter and $50.0 \mathrm{~mm}$ height. Undisturbed soil cores (2 sub-samples per plot) were taken randomly from each treatment at $0-5$ and $5-10 \mathrm{~cm}$ depths using a core sampler. Cores were oven dried at $105^{\circ} \mathrm{C}$ and weighed; BD was calculated as the quotient between the weight of each core and its volume. Penetration resistance (PR) was measured at $0-5$ and $5-10 \mathrm{~cm}$ depths when soil water content was close to field capacity, with an Eijkelkamp penetrologger M1.06.15.E (P.O. Box 4, 6987 ZG Giesbeek, The Netherlands) with a cone basal area of $1 \mathrm{~cm}^{2}$ and a cone angle of $60^{\circ}$. Nine sub-samples per plot were recorded and the results were averaged at the selected depths to get one measurement per plot per depth considered. Soil structural stability was assessed by a dry-wet sieving method (De Boodt et al.,1961). Samples were delicately taken using a shovel from the whole layer $(0-10 \mathrm{~cm})$, when soil water content was close to field capacity. Aggregates in the sample were manually fragmented along their planes of weakness to pass an $8 \mathrm{~mm}$ sieve, exerting the least possible force, and then dried at $30^{\circ} \mathrm{C}$. Dried samples were sieved through a nest of sieves $(4.80,3.36$, and $2.00 \mathrm{~mm}$ opening sieves), and a proportion of each dry fraction obtained was wetted with deionized water and incubated for $24 \mathrm{~h}$ to $35^{\circ} \mathrm{C}$. After that samples were sieved under water through a set of six stacking sieves $(4.80,3.36,2.00,0.84,0.50$, and $0.30 \mathrm{~mm}$ opening sieves) for $30 \mathrm{~min}$. Change in mean weight diameter (CMWD) was calculated as change in diameter of aggregates after being sieved dry and then wet. As CMWD increased soil aggregates were less resistant to water effect.

Management practices such as varieties, plant population, row spacing weeds and insects were chemically controlled with
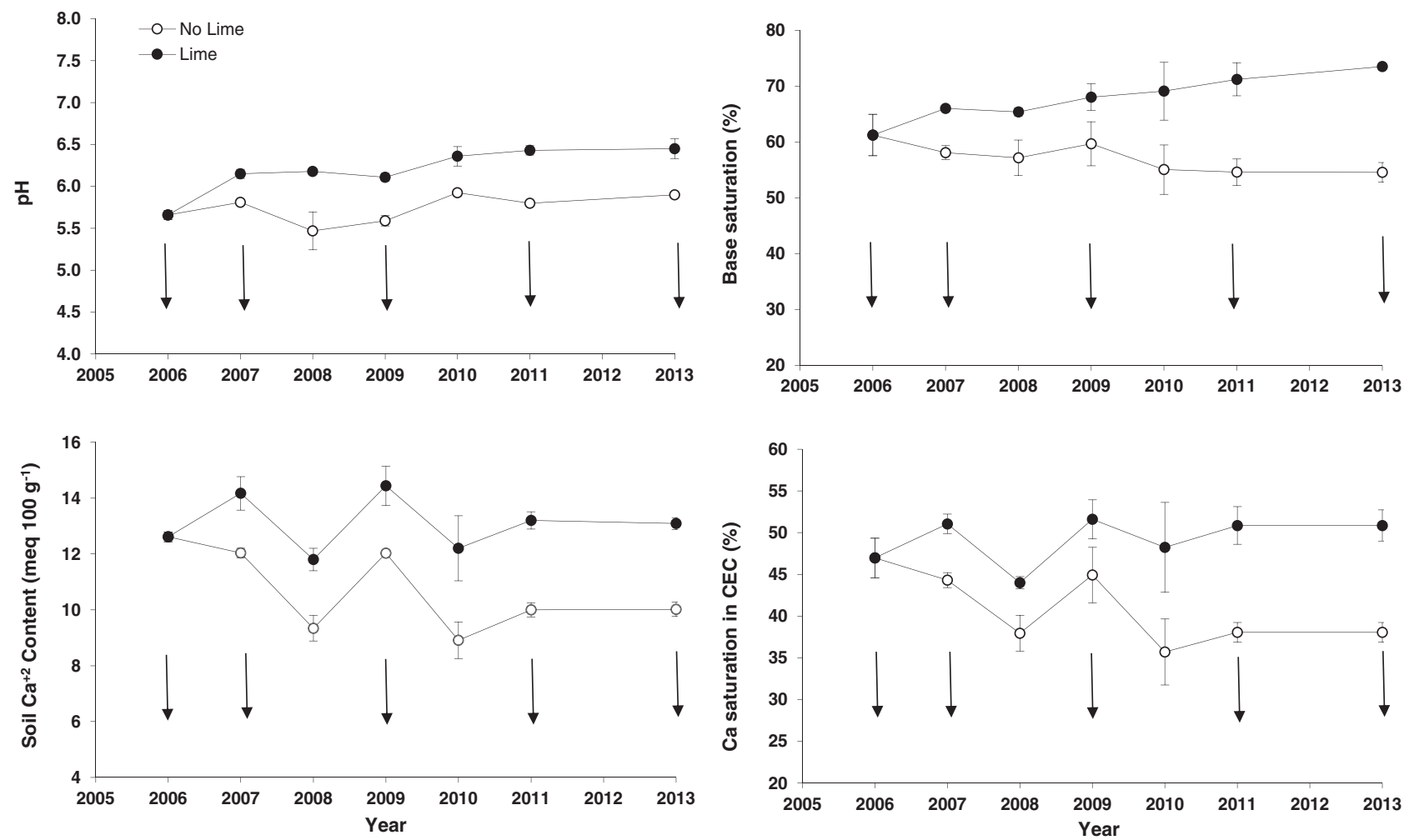

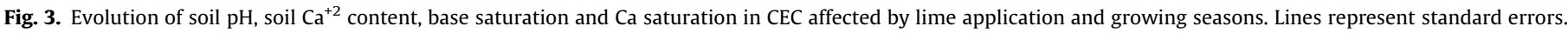
Arrows indicate lime application time. 
recommended products and rates utilized were the same one that those utilized by the farmer. At planting time, experiments were fertilized with $20 \mathrm{~kg} \mathrm{Pha}^{-1}$ as triple superphosphate (0-46-0), and $15 \mathrm{~kg} \mathrm{Sha}^{-1}$ as calcium sulfate (18.6\% of S). Crop evapotranspiration (CET) was determined as the product between potential evapotranspiration $\left(\mathrm{ET}_{0}\right)$ and crop coefficient $\left(K_{c}\right)$. The $\mathrm{ET}_{0}$ was estimates using the Penman-Monteith equation (Allen et al., 1998). The $\mathrm{ET}_{0}$ is defined as the ET rate from a hypothetical grass reference crop with specific characteristics and not short of water (Allen et al., 1998). The $K_{c}$ values $\left(\mathrm{CET} / \mathrm{ET}_{0}\right.$ ) are those reported for the area by Della Maggiora et al. (2000).

Grain yield was measured by experimental combine harvesting an area of $12 \mathrm{~m}^{2}$ ( $10 \mathrm{~m}$ long by $1.2 \mathrm{~m}$ wide), and corrected to 13.5 and $14.0 \%$ grain moisture content for soybean and wheat crops, respectively. Relative grain yield (RY) was calculated as the ratio between average grain yield of non-lime (NL) application treatment divided by average grain yield of lime (L) application treatment multiplied by 100 . Crop relative yield response to lime (relative increase over the control) was calculated as difference between grain yield of lime (L) application and control (NL) divided by the yield of the control (NL) multiplied by 100 .
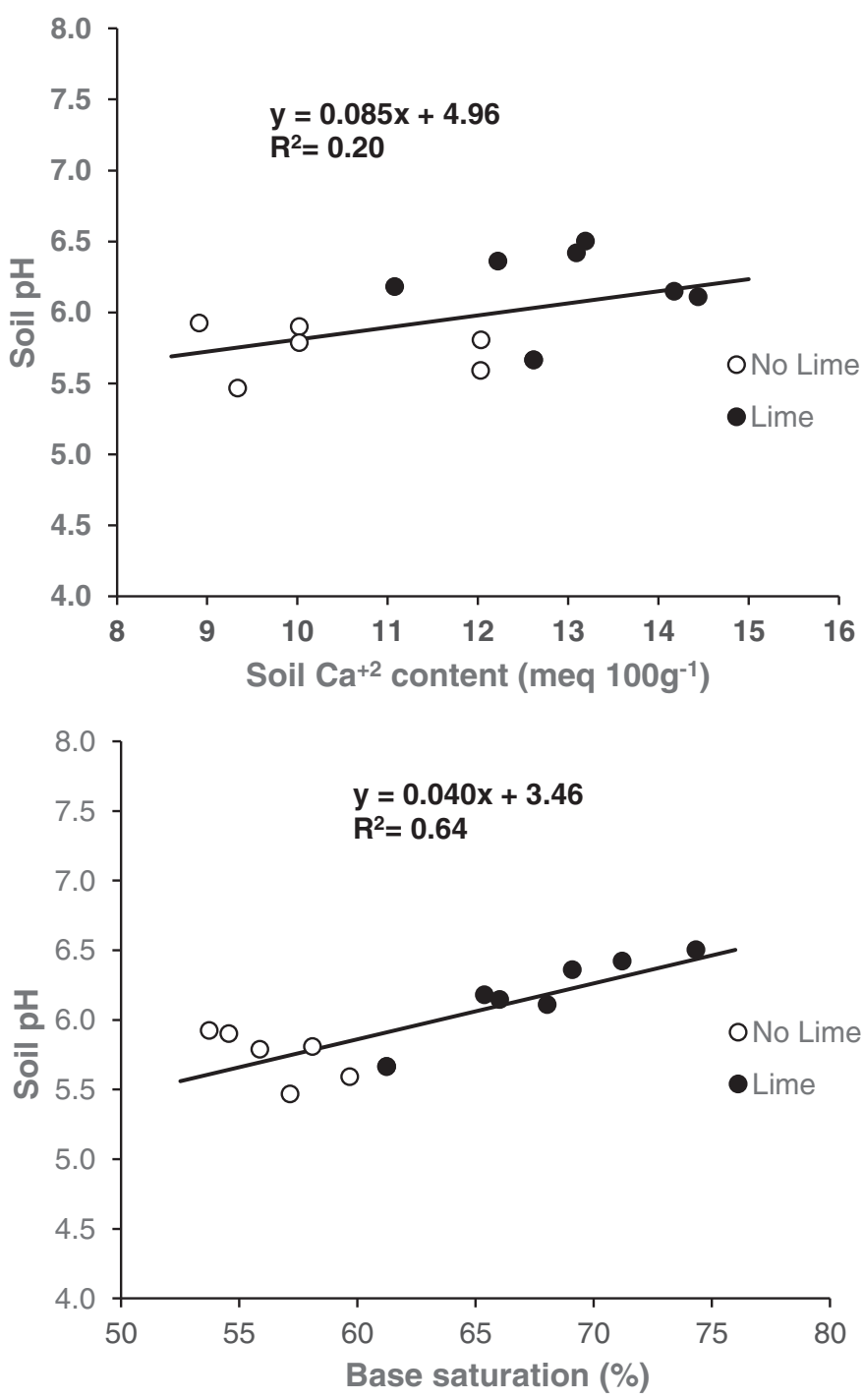

Fig. 4. Relationships between soil pH, soil calcium content, and base saturation.

$$
\begin{aligned}
& \text { Relative yield }=\left(\frac{\text { no lime }}{\text { lime }}\right) \times 100 \\
& \text { Crop relative yield }=\left(\frac{\text { lime }- \text { no lime }}{\text { lime }}\right) \times 100
\end{aligned}
$$

Analysis of variance (ANOVA) was accomplished using the PROC GLM procedure of SAS 9.2 (SAS Institute, 2008). Data were analyzed using a split-plot design. The main plot was the year and the subplot was lime treatments. The means were separated using least significant difference (LSD) at the 0.05 level of significance. Regression and stepway multiple regression analyses were performed using (NLIN) procedure of SAS 9.2 software (SAS Institute, 2008). Soil $\mathrm{Ca}^{+2}$ critical concentrations were calculated with the statistical Cate-Nelson method (Cate and Nelson, 1971) for the soybean grain yield and soil $\mathrm{Ca}^{+2}$ content relationship. The critical concentration for the Cate-Nelson model is the concentration that splits the data into two groups, and the critical concentration for either segmented model is the concentration at which the two portions of the model join.

\section{Results and discussion}

\subsection{Climatic condition}

The water balances for the soybean and wheat crops during the growing seasons are presented in Fig. 2. In general water availability did not limit soybean growth at any growing seasons. Only light water stress events were registered at the beginning of critical kernel set period (Egli et al., 1985; Vega et al., 2001) at 2006/07 and 2007/08 growing season, respectively (Fig. 2). At 2010/11 soybean growing season light water stress events were registered during later December to January and early March. However, these water stresses would lightly affect soybean grain yield.

In the wheat crop at 2008/09 growing season, where the rainfall registered from July to December was only $62 \%(278 \mathrm{~mm})$ of period 1983-2013 (Table 1), a pronounced stress took place during November and December (Fig. 2), a period in which water availability is crucial for obtaining high wheat yields (Calviño and Sadras, 2002). Thus, wheat grain yield was affected by water availability, mainly as consequence of lower kernel number. On the other hand, in the 2010/11, growing season had favorable hydric conditions because rainfall was higher than crop evapotranspiration and therefore no stress was determined (Fig. 2). Multiple analysis regression of grain yield (using as variables rainfall, temperature, crop evapotranspiration and water deficit), determines that water deficit $(p<0.01)$ in the period during 30 days before and 10 days after flowering was the variable that explained variation in yield. These results were agreement with the findings by Calviño and Sadras (2002).

Table 4

Change in mean weight diameter, soil bulk density and penetration resistance in

\begin{tabular}{|c|c|c|c|c|c|}
\hline \multirow[t]{2}{*}{ Treatments depth $(\mathrm{cm})$} & \multirow{2}{*}{$\begin{array}{l}\text { CMWD }(\mathrm{mm}) \\
0-10\end{array}$} & \multicolumn{2}{|c|}{$\mathrm{BD}\left(\mathrm{Mg} \mathrm{m}^{-3}\right)$} & \multicolumn{2}{|c|}{ PR (M Pa) } \\
\hline & & $0-5$ & $5-10$ & $0-5$ & $5-10$ \\
\hline No lime & $0.31 \mathrm{a}$ & $1.19 \mathrm{a}^{1}$ & $1.29 \mathrm{a}$ & $0.98 a$ & $1.66 \mathrm{a}$ \\
\hline Lime & $0.22 b$ & $1.21 \mathrm{a}$ & $1.28 \mathrm{a}$ & $1.01 \mathrm{a}$ & $1.43 a$ \\
\hline$p$ & 0.023 & 0.509 & 0.651 & 0.860 & 0.189 \\
\hline
\end{tabular}
2010/11 growing season.

MWD, change in mean weight diameter; $\mathrm{BD}$, bulk density; PR, penetration resistance.

${ }^{1}$ Means followed by the same letter are not significantly different from each other based on the LSD test. 
Table 5

Soybean and wheat grain yield as affected by lime application and growing seasons, and cumulative grain yield as affected by lime application.

\begin{tabular}{|c|c|c|c|c|c|c|c|c|c|c|}
\hline \multirow[t]{2}{*}{ Treatment } & \multicolumn{6}{|c|}{ Soybean grain yield $\left(\mathrm{kg} \mathrm{ha}^{-1}\right)$} & \multicolumn{3}{|c|}{ Wheat grain yield $\left(\mathrm{kg} \mathrm{ha}^{-1}\right)$} & \multirow[t]{2}{*}{ Cumulative grain yield $\left(\mathrm{kg} \mathrm{ha}^{-1}\right)$} \\
\hline & $2006 / 07$ & $2007 / 08$ & $2009 / 10$ & $2010 / 11$ & $2013 / 14$ & Average & $2008 / 09$ & $2010 / 11$ & Average & \\
\hline Lime & 4226 & 3377 & 4607 & 1057 & 3355 & $3225 a$ & 4483 & 7523 & $6003 a^{1}$ & $28629 a^{1}$ \\
\hline No lime & 4176 & 3060 & 4234 & 997 & 3103 & $3114 b$ & 4585 & 7401 & 5993a & $27556 b$ \\
\hline Average & 4201a & $3218 b$ & $4420 a$ & $1027 \mathrm{c}$ & $3229 b$ & - & $4534 b$ & $7462 a$ & - & 0.0455 \\
\hline Treatment $(T)$ & 0.0356 & & & & & & 0.967 & & & \\
\hline $\operatorname{Year}(Y)$ & 0.0001 & & & & & & 0.001 & & & \\
\hline$T \times Y$ & 0.6810 & & & & & & 0.645 & & & \\
\hline
\end{tabular}

1 Means followed by the same letter are not significantly different from each other based on the LSD test.

\subsection{Soil determination}

In 2006 growing season, tritatable acidity was 11.2 meq $100 \mathrm{~g}$ soil $^{-1}$, exchangeable acidity was 0.12 meq $100 \mathrm{~g} \mathrm{soil}^{-1}$ and, $\mathrm{Al}^{+3}$ was not detected, and therefore crop yield may not be decreased by $\mathrm{Al}$ toxicity. Similar values of tritatable and exchangeable acidity were reported by Fabrizzi (1998) in the same region for agricultural soils.

After seven years of experiment, significant changes were determined on soil $\mathrm{pH}$, soil $\mathrm{Ca}^{+2}$ content, base saturation, and $\mathrm{Ca}^{+2}$ saturation in CEC by lime application (Table 2). In the lime pots increase of 14, 5, 21 and $9 \%$ were determined for soil $\mathrm{pH}$, soil $\mathrm{Ca}^{+2}$ content, base saturation, and $\mathrm{Ca}^{+2}$ saturation in $\mathrm{CEC}$, respectively (Table 2). In the no lime plots small changes in soil $\mathrm{pH}$ was determined; however, reduction of 21,11 , and $19 \%$ were determined in soil $\mathrm{Ca}^{+2}$ content, base saturation, and $\mathrm{Ca}^{+2}$ saturation in CEC, respectively (Table 2). Caires et al. (2011a,b); Caires et al. (2011a,b) determined significantly changes in soil properties in a long term experiment (7-8 years) by lime or gypsum application.

Significant interaction (year $\times$ lime) was observed on soil $\mathrm{pH}$, soil $\mathrm{Ca}^{+2}$ content, base saturation and $\% \mathrm{Ca}^{+2}$ saturation in CEC (Table 3 ). Soil $\mathrm{pH}$ was significantly affected by years and lime application (Table 3). Average soil $\mathrm{pH}$ by years ranged from 5.7 to 6.2, and was high in 2011, 2010 and 2013 (i.e., 6.14, 6.12 and 6.18, respectively), medium 2007 (5.98) and low 2008 and 2009 (i.e., 5.83 and 5.85, respectively). Higher soil pH values (2010, 2011 and 2013) were consequence of accumulative effects of previous lime application. Medium or lower soil $\mathrm{pH}$ were determined at the beginning of experiment or year without lime application (20072009). Lime application increased significantly soil pH from 5.7 at the beginning in 2006 to 6.5 in 2013/14 growing season, whereas no lime treatment showed $\mathrm{pH}$ values ranging from 5.7 to 5.9 across years (Fig. 3). The average increment in soil pH across year in response to lime application was $6 \%$. Soil $\mathrm{Ca}^{+2}$ content was significantly affected by year and lime application (Table 3 ). Average soil $\mathrm{Ca}^{+2}$ content by years ranged from 10.6 to

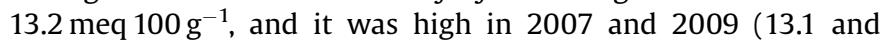
$13.2 \mathrm{meq} 100 \mathrm{~g}^{-1}$, respectively), medium in 2011 and 2013
(11.6 meq $100 \mathrm{~g}^{-1}$, and $11.5 \mathrm{meq} 100 \mathrm{~g}^{-1}$, respectively) and low in 2008 and 2010 (10.8 and 10.8 meq $100 \mathrm{~g}^{-1}$, respectively). Soil $\mathrm{Ca}^{+2}$ content ranged from 12.6 to 13.9 in lime treatment and 12.6 to 10.0 in no lime treatment from 2006 to 2014 growing seasons, respectively (Fig. 3 ). The average increment in soil $\mathrm{Ca}^{+2}$ content across years in response to lime application was $11.8 \%$ (Fig. 3). Base saturation only was increased significantly by lime application (Table 3). Base saturation at 2006 was 61\%, and at 2014 growing season were 74 and $55 \%$ to lime and no lime treatments, respectively (Fig. 3 ). The increment in base saturation in response to lime application was by $20.1 \%$. Calcium saturation in CEC was significantly affected only by lime application (Table 3 ). Calcium saturation in CEC at 2006 was $47.0 \%$ and at 2014 growing season were 38.1 and $50.9 \%$ to lime and no lime treatments, respectively (Fig. 3). The increment in $\mathrm{Ca}^{+2}$ saturation in response to lime application was by $8.3 \%$. A positive and significant $(p<0.05)$ association was determined between soil $\mathrm{pH}$ and soil $\mathrm{Ca}^{+2}$ content, and soil $\mathrm{pH}$ and base saturation (Fig. 4). The greater $R^{2}$ determined by soil $\mathrm{pH}$ and base saturation than soil $\mathrm{pH}$ and soil $\mathrm{Ca}^{+2}$ content relationships $\left(R^{2}=0.64\right.$ vs 0.20$)$ indicates that other ions affected soil $\mathrm{pH}$ variation. Similar relationships between soil $\mathrm{pH}$ and base saturation were informed by Caires et al. (2000, 2006a),) and Alleoni et al. (2010) from Brazilian soils. These authors reported that soil $\mathrm{pH}$ increased by lime applications was accompanied by increase on base saturation. Several experiments reported increments in soil $\mathrm{pH}$, soil $\mathrm{Ca}^{+2}$ content, base saturation and $\% \mathrm{Ca}^{+2}$ saturation in CEC by lime application (Caires et al., 2006a, 2010; Moreira and Fagaria, 2010; Pagani and Mallarino, 2012; GómezPaccard et al., 2013; Fagaria et al., 2014)

Soil bulk density and penetration resistance (PR) were not affected by lime application (Table 4). The results our experiment do not agree with informed by Chan et al. (2007) and Scott et al. (2003) who determined significantly reduction in BD and PR for lime application, respectively. In spite of this, BD or PR data were lower in lime than in no lime treatments (Table 4). However, significant change in CMWD was determined by lime application (Table 4). Liming affected the aggregate binding agents, in soils
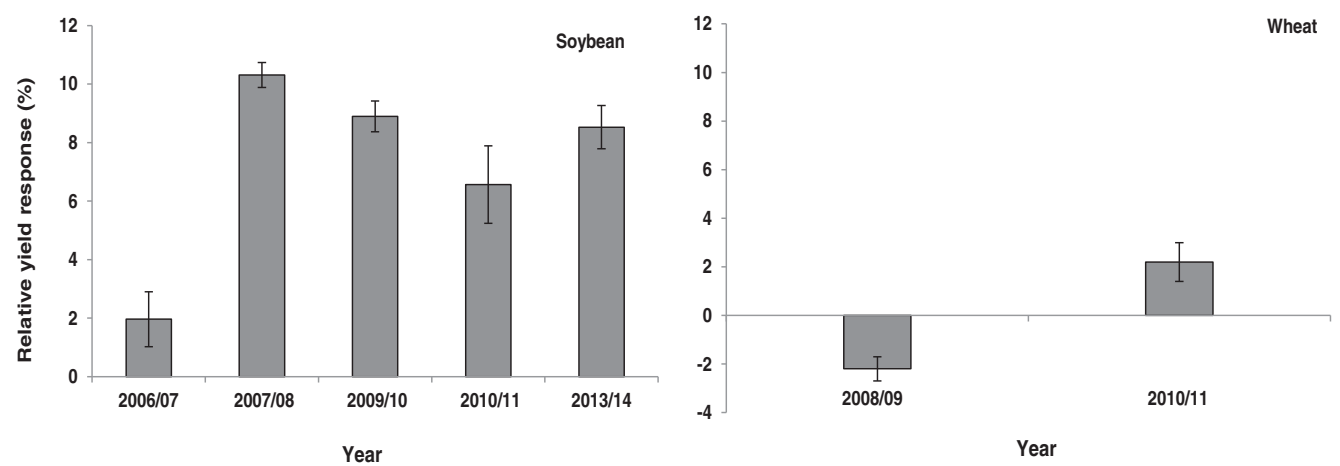

Fig. 5. Relative grain yield response to lime application by soybean and wheat crop. Lines represent standard errors. 

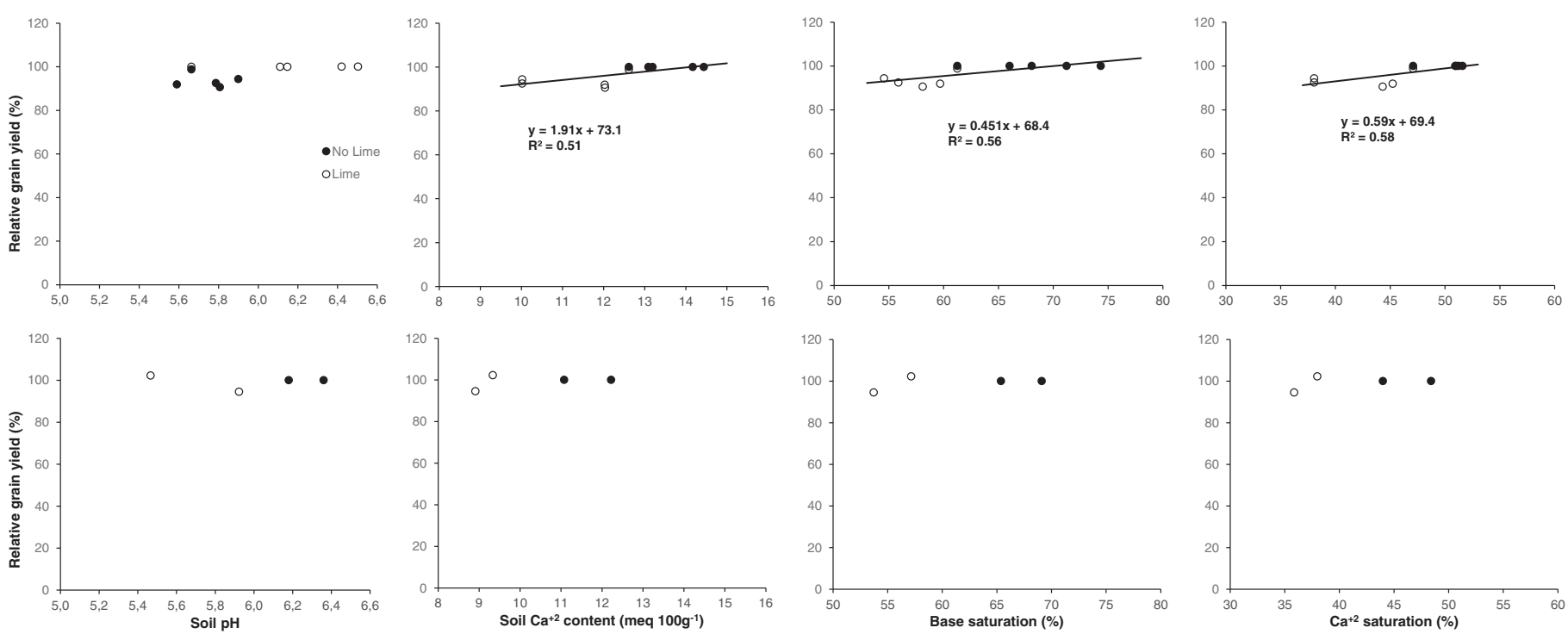

Fig. 6. Relationships between relative grain yield and soil $\mathrm{pH}$, soil $\mathrm{Ca}^{+2}$ content, base saturation (BS) and calcium saturation in cation exchangeable capacity for soybean and wheat crops. 
Table 6

Regression models for relationships between relative grain yield (RY) and soil pH, soil calcium content, base saturation and calcium saturation in cation exchangeable capacity for soybean and wheat crops.

\begin{tabular}{|c|c|c|c|}
\hline & \multicolumn{3}{|l|}{ Soybean } \\
\hline & Equation & $R^{2}$ & $p$ \\
\hline $\mathrm{pH}$ & $R Y=49.3+7.99 x$ & 0.30 & 0.09 \\
\hline Soil $\mathrm{Ca}^{+2}$ content & $\mathrm{RY}=71.9+1.98 \mathrm{x}$ & 0.56 & 0.01 \\
\hline Base saturation & $R Y=61.9+0.54 x$ & 0.49 & 0.02 \\
\hline \multirow[t]{3}{*}{$\mathrm{Ca}^{+2}$ saturation } & $\mathrm{y}=58.0+0.80 \mathrm{x}$ & 0.64 & 0.01 \\
\hline & \multicolumn{3}{|l|}{ Wheat } \\
\hline & Equation & $R^{2}$ & $p$ \\
\hline $\mathrm{pH}$ & $R Y=110.4-1.88 x$ & 0.05 & 0.84 \\
\hline Soil $\mathrm{Ca}^{+2}$ content & $\mathrm{RY}=91.6+0.72 x$ & 0.14 & 0.63 \\
\hline Base saturation & $\mathrm{RY}=87.0+0.19 x$ & 0.15 & 0.60 \\
\hline $\mathrm{Ca}^{+2}$ saturation & $\mathrm{RY}=89.4+0.24 x$ & 0.17 & 0.60 \\
\hline
\end{tabular}

with illite dominance, and secondarily, montmorillonite in the clay fraction would promote the formation of cementing process of $\mathrm{Ca}^{+2}$ between mineral and organic fractions, exercising soil structuration (Vázquez et al., 2009; Clever et al., 2012). Positive effect on aggregate stability and soil aggregation by lime application were informed by Chan et al. (2007), Hati et al. (2008), Chaplain et al. (2011), Arshad et al. (2012) and Bennett et al. (2014).

\subsection{Grain yield}

No significant interaction (year $\times$ lime) was observed on soybean and wheat crops grain yield. Soybean grain yield was affected by year $(p<0.01)$ and lime application $(p<0.05)$, grain yield ranged from 1000 to $4500 \mathrm{~kg} \mathrm{ha}^{-1}$ depending on growing season, the lower value corresponding to double crop wheat/ soybean (Table 5). Lime application increased average soybean grain yield $7 \%$, which coincides with the findings by others authors (Caires et al., 2005; Costa and Rosolem, 2007; Vázquez et al., 2010; Pagani and Mallarino, 2012; Castro and Crusciol, 2013). The grain yield increments in response to lime application varied from 2 to $10 \%$ depending to growing season (Fig. 5).

Wheat grain yield was affected only by year $(p<0.01)$. In the 2008 growing season, a pronounced stress took place during November (Fig. 2), which was reflected in crop yields $(4500 \mathrm{~kg}$ $\mathrm{ha}^{-1}$ ) while in 2011 growing season higher grain yield $(7500 \mathrm{~kg}$ $\mathrm{ha}^{-1}$ ) was obtained as consequence of favorable hydric conditions. No significant differences were determined for lime application on wheat grain yield (Table 5). These results are in agreement with

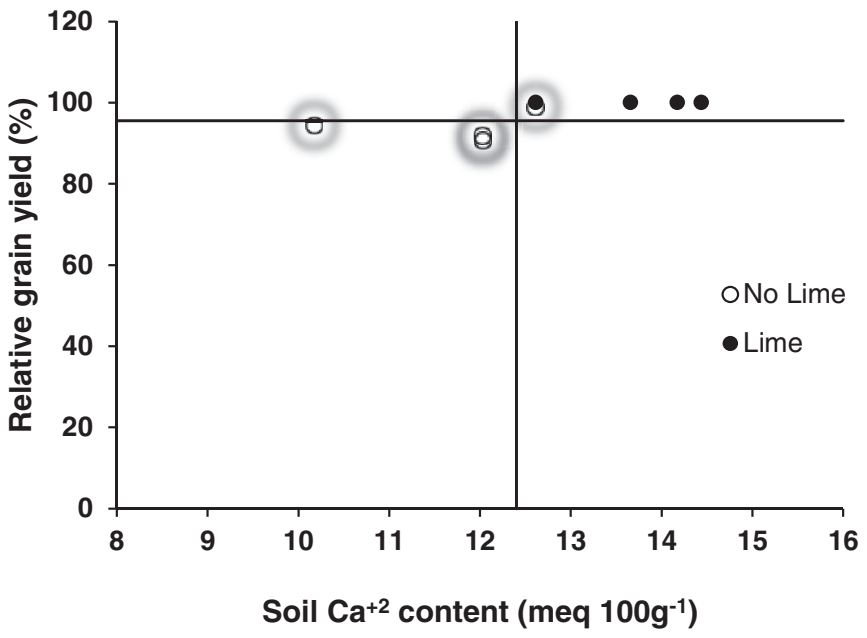

Fig. 7. Relationship between relative grain yield and soil $\mathrm{Ca}^{+2}$ content. those obtained in other reports (Caires et al., 1999, 2002; Liu et al., 2004; Brown et al., 2008; Pisa Lollato et al., 2013). The grain yield increments in response to lime application were -2.2 to $2.2 \%$ in 2008 and 2011 growing season, respectively (Table 5). The negative grain yield response determined in the lime treatment in 2008 growing season, would be consequence to greater dry matter accumulated during vegetative stages (17\%) compared to no lime application treatments. This situation would lead to more crop water consumption and, therefore, water stress was more pronounced during critical period to kernel set (data not sown). Cumulative grain yield was significantly effected $(p<0.05)$ by lime application (Table 5 ) indicating that the benefits of liming were cumulative over time, in spite of wheat grain yield variability. Similar results were reported by others (Caires et al., 2000, 2006b; Arshad et al., 2012; Fageria et al., 2013, 2014).

The major grain yield response to lime application, determined in soybean than wheat crop, would be consequence to growth responses in leguminous attributed to favorable soil $\mathrm{pH}$ for rhizobium activity (Mengel and Kamprat, 1978; Brauer et al., 2002; Ouertatania et al., 2011). Optimum soil range $\mathrm{pH}$ for soybean and wheat is around 5.5-7.5 for both crops (Fageria and Zimmermann, 1998; Bongiovanni and Lowenberg-DeBoer, 2000; Sawyer et al., 2002; Pagani, 2011). However, no significant relationship was determined between $\mathrm{RY}$ and soil $\mathrm{pH}$ in both crops, in spite of $\mathrm{pH}$ values in no lime treatment was from 5.5 to 5.9 (Fig. 6, Table 6). Only in soybean crop, a significant relationship was determined between RY and soil $\mathrm{Ca}^{+2}$ content $\left(R^{2}=0.51\right)$, base saturation $\left(R^{2}=0.56\right)$ and, $\mathrm{Ca}^{+2}$ saturation in CEC $\left(R^{2}=0.58\right)$ (Fig. 6, Table 6). Significant and positive correlation between soybean grain yield and soil Ca and base saturation were informed by others (Costa and Rosolem, 2007; Fageria, 2008; Dalla Nora and Amado, 2013; Fageria et al., 2014). A significant $\left(p<0.01 ; R^{2}=0.26\right)$ soil critical $\mathrm{Ca}^{+2}$ content was determined to obtain $95 \%$ of relative grain yield only for responsive soybean crop (Fig. 7). The critical value of $12.4 \mathrm{meq} 100 \mathrm{~g}^{-1}$ was greater than $3.8 \mathrm{meq} 100 \mathrm{~g}^{-1}$ (Fageria et al., 2010) for common beans, and $4 \mathrm{meq} 100 \mathrm{~g}^{-1}$ (Fageria, 2001), 1.8 meq $100 \mathrm{~g}^{-1}$ (Fageria et al., 2013) and $1.6 \mathrm{meq} 100 \mathrm{~g}^{-1}$ (Fageria et al., 2014) for soybean.

The response to lime application on soybean would be consequence of $\mathrm{Ca}^{+2}$ saturation content in CEC, which for no lime treatment ranged from $47 \%$ (2006) at the beginning of experiment and 37\% in 2013-14 growing season. These values were below 67\% reported by Fageria (2008) for no-till bean; Eckert (1987) reviewed work of many studies and reported that ideal Ca saturation should be around 65\%. High Ca saturation indicates a favorable $\mathrm{pH}$ for plant growth and microbial activity and will usually reflect low exchangeable $\mathrm{Al}^{+3}$ in acid soils and $\mathrm{Na}^{+}$ in in sodic soils (Havlin et al., 2005). Lime application would produce a several chemical and biological changes in the soil, which are beneficial or helpful in improving crop yield (Bennett et al., 2014). On the other hand, soybean in particular, is a highly demanding crop in Ca; this requirement are about $16 \mathrm{~kg} \mathrm{Tn}^{-1}$, while in wheat are about $4 \mathrm{~kg} \mathrm{Tn}^{-1}$ (Ciampitti and García, 2007). Regarding the influence of $\mathrm{Ca}^{+2}$ on the production of soybean, it would be desirable to increase soil Ca available levels rather than increasing $\mathrm{pH}$, as consequence of decreased levels of $\mathrm{Ca}^{+2}$ in CEC. Therefore, lime rates would be lower applied on those required to increase the soil pH (Fontanetto et al., 2009). Alternative application strategies such as placement of lime in a band beneath the row at seeding could be used to Ca fertilization.

\section{Conclusion}

Lime application increased soil $\mathrm{pH}$, soil $\mathrm{Ca}^{+2}$ content, base saturation and $\mathrm{Ca}^{+2}$ content in CEC. Wheat grain yield was not affected by lime, but soybean grain yield was significantly 
increased by lime. Increments in relative grain yield were not associated with soil $\mathrm{pH}$ in both crops; however, significant relationships were determined between relative soybean grain yield and soil $\mathrm{Ca}^{+2}$ content, base saturation and $\mathrm{Ca}^{+2}$ content in CEC. A soil $\mathrm{Ca}^{+2}$ critical concentration of $12.4 \mathrm{meq} 100 \mathrm{~g}^{-1}$ was determined to obtain $95 \%$ of relative soybean grain yield. These results would indicate that soil $\mathrm{Ca}^{+2}$ content would limit soybean grain yield as a consequence of cation unbalance in intensive agriculture soil.

\section{Acknowledgments}

This study was supported by the INTA Project PNSUELO 1134024, and FONCyT-PICT 2011-796.

\section{References}

Allen, R.G., Pereira, L.S., Raes, D., Smith, M., 1998. Crop evapotranspiration guidelines for computing crop water requirements. FAO Irrigation and Drainage Paper 56. Food and Agriculture Organization of the United Nations, Rome.

Alleoni, L.R.F., Cambri, M.A., Caires, E.F., Garbuio, F.J., 2010. Acidity and aluminum speciation as affected by surface liming in tropical no-till soils. Soil Sci. Soc. Am. J. 74, 1010-1017.

Arshad, M.A., Soon, Y.K., Azooz, R.H., Lupwayi, N.Z., Chang, S.X., 2012. Soil and crop response to wood ash and lime application in acidic soils. Agron. J. 104, 715-721.

Barbieri, P.A., Echeverría, H.E., Sainz Rozas, H.R., 2012. Alternatives of nitrogen diagnosis for wheat with different yield potential in the humid pampas of Argentina. Commun. Soil Sci. Plant Anal. 43, 1512-1522.

Bennett, J. McL, Greene, R.S.B., Murphy, C.B.W., Hocking, P., Tongway, D., 2014. Influence of lime and gypsum on long-term rehabilitation of a red sodosol, in a semi-arid environment of New South Wales. Soil Res. 52, 120-128.

Brady, N.C., Weill, R.W., 1999. The nature and properties of soil, Twentieth ed. Prentice-Hall Inc., Simona and Schuster A Viacon Company, Upper Saddle River, New Jersey, USA.

Bray, R.H., Kurtz, L.T., 1945. Determination of total organic, and available forms of phosphorus is soils. Soil Sci. 59, 39-45.

Blake, G.R., Hartge, K.H., 1986. Bulk density. In: Klute, A. (Ed.), Methods of Soil Analysis. Part 1. Physical and Mineralogical Methods. American Society of Agronomy, the Soil Science Society of America, Madison, WI, USA, pp. 363-375.

Bongiovanni, R., Lowenberg-DeBoer, J., 2000. Nitrogen management in corn using site-specific crop response estimates from a spatial regression model. In: Robert, P.C., Rust, R.H., Larson, W.E. (Eds.), Proceedings of the 5th Internationa Conference on Precision Agriculture. American Society of Agronomy, Crop Science Society of America, Soil Science Society of America, Madison, WI, pp. 2000.

Bouman, O.T., Curtin, D., Campbell, C.A., Biederbeck, V.O., Ukrainetz, H., 1995. Soil acidification from long-term use of anhydrous ammonia and urea. Soil Sci. Soc. Am. J. 59, 1488-1494.

Brauer, D., Ritchey, D., Belesky, D., 2002. Effects of lime and calcium on root development and nodulation of clovers. Crop Sci. 42, 1640-1646.

Brown, T.T., Koenig, R.K., Huggins, D.R., Harsh, J.B., Rossi, R.E., 2008. Lime effects on soil acidity crop yield, and aluminum chemistry in direct-seeded cropping systems. Soil Sci. Soc. Am. J. 72, 634-640.

Caires, E.F., Fonseca, A.F., Mendes, J., Chueiri, W.A., Madruga, E.F., 1999. Produção de milho, trigo e soja em função das alterações das características químicas do solo pela aplicação de calcário e gesso na superfície, em sistema de plantio direto. Rev. Bras. Ciênc. Solo 23, 315-327.

Caires, E.F., Banzatto, D.A., Fonseca, A.F., 2000. Calagem na superficie em sistema plantio direto. R. Bras. Ciên. Solo 24, 161-169.

Caires, E.F., Feldhaus, I.C., Barth, G., Garbuio, F.J., 2002. Lime and gypsum application on the wheat crop. Sci. Agric. 59, 357-364.

Caires, E.F., Alleoni, L.R.F., Cambri, M.A., Barth, G., 2005. Surface application of lime for crop grain production under a no-till system. Agron. J. 97, 791-798.

Caires, E.F., Cristovão, J., Corrêa, L., Churka, S., Barth, G., Garbuio, F.J., 2006a. Surface application of lime ameliorates subsoil acidity and improves root growth and yield of wheat in an acid soil under no-till system. Sci. Agric. 63, 502-509.

Caires, E.F., Barth, G., Garbuio, F.J., 2006b. Lime application in the establishment of a no-till system for grain crop production in Southern Brazil. Soil Till. Res. 89, $3-12$.

Caires, E.F., Joris, H.A.W., Churka, S., 2011a. Long-term effects of lime and gypsum additions on no-till corn and soybean yield and soil chemical properties in southern Brazil. Soil Use Manage. 27, 37-45.

Caires, E.F., Garbuio, F.J., Churka, S., Joris, H.A.W., 2011b. Use of gypsum for crop grain production under a subtropical no-till cropping system. Agron. J. 103 1804-1814.

Calviño, P.A., Sadras, V.O., 2002. On-farm assessment of constraints to wheat yield in the south-eastern Pampas. Field Crops Res. 74, 1-11.

Castro, G.S.A., Crusciol, C.A.C., 2013. Effects of superficial liming and silicate application on soil fertility and crop yield under rotation. Geoderma 195-196, 234-242.
Cate Jr., R.B., Nelson, L.A., 1971. A simple statistical procedure for partitioning soil test correlation data into two classes. Soil Sci. Soc. Am. Proc. doi:http://dx.doi. org/10.2136/sssaj1971.03615995003500040048x.

Chapman, H.D., 1965. Cation exchange capacity. In: Black, C.A. (Ed.), Methods of Soil Analysis. Part 2. Number 9 in the Series Agronomy. American Institute of Agronomy, Madison, Wisconsin, pp. 891-901.

Ciampitti, I.A., García, F.O., 2007. Requerimientos nutricionales de macronutrientes y nutrientes secundarios. I. Cereales, Oleaginosas e Industriales. Informaciones Agronómicas No. 47, Archivo Agronómio No.11. IPNI Cono Sur. Acassuso. Buenos Aires, Argentina

Costa, A., Rosolem, C.A., 2007. Liming in the transition to no-till under a wheatsoybean rotation. Soil \& Till. Res. 97, 207-217.

Chan, K.Y., Conyers, M.K., Scott, B.J., 2007. Improved structural stability of an acidic hardsetting soil attributable to lime application. Commun. Soil Sci. Plant Anal. $38,15-16$.

Clever, B., de Moraes Sá, J.C., Caires, E.F., Navarro, J.F., Inagaki, A.B., Boer, A., Quadros Neto, C., de Oliveira Ferreira, A., Canalli, L.B., dos Santos, J.B., 2012. Soil organic matter pools and carbon-protection mechanisms in aggregate classes influenced by surface liming in a no-till system. Geoderma 170, 80-88.

Dalla Nora, D., Amado, T.J.C., 2013. Improvement in chemical attributes of oxisol subsoiland crop yields under no-till. Agron. J. 105, 1393-1403.

De Boodt, M., De Leenher, L., Kirham, D., 1961. Soil aggregate stability indexes and crop yields. Soil Sci. 91, 138-146.

Della Maggiora, A.I., Gardiol, J.M., Irigoyen, A.I., 2000. Requerimientos hídricos. In: Andrade, F.H., Sadras, V.O. (Eds.), Bases para el manejo del maíz, el girasol y la soja. EEA INTA Balcarce-FCA UNMdP, Balcarce, Argentina, pp. 155-171.

Egli, D.B., Guffy, R.D., Leggett, J.E., 1985. Partitioning of assimilate between vegetative and reproductive growth in soybean. Agron. J. 77, 917-922.

Eckert Eckert, D.J., 1987. Soil test interpretations: basic cation saturation ratios and sufficiency levels. In: Brown, J.R. (Ed.), Soil Testing: Sampling, Correlation, Calibration, and Interpretation. SSSA, Madison, WI, pp. 53-64.

Fabrizzi, K., 1998. Efecto a largo plazo de la fertilización nitrogenada y fosfatada sobre las propiedades químicas del suelo. Tesis de graduación. Universidad Nacional de Mar del Plata, Facultad de Ciencias, Agrarias, Balcarce.

Fageria, N.K., Zimmermann, F.J.P., 1998. Influence of pH on growth and nutrient uptake by crop species in an Oxisol. Commun. Soil Sci. Plant Anal. 29 2675-2682.

Fageria, N.K., 2001. Response of upland rice, dry bean, corn, and soybean to base saturation in cerrado soil. Revista Brasileira de Engenharia Agricola e Ambiental $5,416-424$.

Fageria, N.K., 2008. Optimum soil acidity indices for dry bean production on an oxisol in no-tillage system. Commun. Soil Sci. Plant Anal. 39, 845-857.

Fageria, N.K., dos Santos, A.B., Moreira, A., 2010. Yield, nutrient uptake, and changes in soil chemical properties as influenced by liming and iron application in common bean in a no-tillage system. Comm. in Soil Sci. and Plant Anal. 41, $1740-1749$.

Fageria, N.K., Moreira, A., Castro, C., Moraes, L.A.C., 2013. Optimal acidity indices for soybean production in Brazilian oxisols. Commun. Soil Sci. Plant Anal. 44, 2941-2951.

Fageria, N.K., Moreira, A., Moraes, L.A.C., Moraes, M.F., 2014. Influence of lime and gypsum on yield and yield components of soybean and changes in soil chemical properties. Commun. Soil Sci. Plant Anal. 45, 271-283.

Fontanetto, H., Keller, O., Albrecht, J., Giailevra, D., Negro, C., Belotti, L., 2009. Manejo de la fertilización de la soja en la región pampeana norte y en el NOA argentino. In: García, F.O., Ciampitti, I. (Eds.), Simposio Fertilidad 2009. Mejores Prácticas de Manejo para una Mayor Eficiencia en la Nutrición de los Cultivos. International Plant Nutrition Institute, Rosario, pcia. de Santa Fe, pp. 109-118.

Gambaudo, S., Fontanetto, H., 2011. Diagnóstico de la acidez edáfica y su corrección. In: García, F.O., Correndo, A.A. (Eds.), Simposio Fertilidad 2011. La nutrición de cultivos integrada al sistema de producción. International Plant Nutrition Institute, Rosario, pcia. de Santa Fe.

Godsey, B., Ch, Pierzynski, G.M., Mengel, D.B., Lamond, R.E., 2007. Management of soil acidity in no-till production systems through surface application of lime. Agron. J. 99, 764-772.

Gómez-Paccard, C., Mariscal-Sancho, I., León, P., Benito, M., González, P., Ordóñez, R., Espejo, R., Hontoria, C., 2013. Ca-amendment and tillage: medium term synergies for improving key soil properties of acid soils. Soil and Tille Res. 134, 195-206.

Hati, K.M., Swarupb, A., Mishrac, B., Mannaa, M.C., Wanjaria, R.H., Mandala, K.G. Misraa, A.K., 2008. Impact of long-term application of fertilizer, manure and lime under intensive cropping on physical properties and organic carbon content of an alfisol. Geoderma 148, 173-179.

Havlin, J.L., Beaton, J.D., Tisdale, S.L., Nelson, W.L., 2005. Sulfur, Calcium, and Magnesium, Soil Fertility and fertilizers: an introduction to nutrient management. 7th ed. Pearson Prentice Hall, Upper Saddle River, New Jersey, pp. 219-243.

Joris, H.A.W., Caires, E.F., Bini, A.R., Scharr, D.A., Haliski, A., 2013. Effects of soil acidity and water stress on corn and soybean performance under a no-till system. Plant Soil 365, 409-424.

Liu, D.L., Helyar, K.R., Conyers, M.K., Fisher, R., Poile, G.J., 2004. Response of wheat: triticale and barley to lime application in semi-arid soils. Field Crops Res. 90, 287-301.

Martínez, P.J., Barbieri, P.A., Sainz Rozas, H.R., Echeverría, H.E., 2013. Inclusion of cover crops in cropping sequences with soybean predominance in the southeast of the humid Argentine pampa. Open Agric. J. 7 (Suppl. 1), 3-10. 
Mengel, D.B., Kamprat, E.J., 1978. Effect of soil pH and liming on growth and nodulation of soybeans in histosols. Agron. J. 70, 959-963.

Ouertatania, S., Regayaa, K., Ryanb, J., Gharbic, A., 2011. Soil liming and mineral fertilization for root nodulation and growth of faba beans in an acid soil in Tunisia. J. Plant Nutr. 850-860.

Pagani, A., 2011. Soil pH and lime management for corn and soybean graduate. Theses and Dissertations. Paper 10,374. Iowa State University.

Pagani, A., Mallarino, A.P., 2012. Soil pH and crop grain yield as affected by the source and rate of lime. Soil Sci. Soc. Am. J. 76, 1877-1886.

Peech, M., et al., 1965. Lime requirement. In: Black, C.A. (Ed.), Methods of Soil Analysis. Part 2. Chemical and Microbiological Methods. Agronomy Monograph 9. ASA, Madison, WI, pp. 927.

Pisa Lollato, R., Edwards, J.T., Zhang, H., 2013. Effect of alternative soil acidity amelioration strategies on soil $\mathrm{pH}$ distribution and wheat agronomic response. Soil. Sci. Soc. Am. J. 30, 1831-1841.

Sainz Rozas, H.R., Calviño, P.A., Echeverría, H.E., Barbieri, P.A., Redolatti, M., 2008. Contribution of anaerobically mineralized nitrogen to planting or presidedress soil nitrogen test in maize. Agron. J. 100, 1020-1025.

Sainz Rozas, H.R., Echeverría, H.E., Angelini, H.P., 2011. Niveles de carbono orgánico y $\mathrm{pH}$ en suelos agrícolas de la región pampeana y extrapampeana argentina. Cienc. Suelo 29, 29-37.

Sainz Rozas, H.R., Echeverría, H.E., Angelini, H.P., 2012. Fósforo disponible en suelos agrícolas de la región Pampeana y ExtraPampeana argentina. Rev. Inv. Agrop. 38, 33-39.

Sainz Rozas, H., Eyherabide, M., Echeverria, H.E., Barbieri, P.A., Angelini, H.P., Larrea, G.E., 2013. ¿Cuál es el estado de la fertilidad de los suelos argentinos? In: García, F.O., Correndo, A.A. (Eds.), Simposio Fertilidad 2013. Nutrición de cultivos para la intensificación productiva sustentable. International Plant Nutrition Institute, Rosario pcia. de Santa Fe, pp. 62-72.

SAS Institute, 2008. SAS/STAT user's guide, Version 9.2. SAS Institute, Cary, NC.

Sawyer, A.P., Mallarino, R., Killorn, S.K., 2002. Barnhart General guide for crop nutrient recommendations in Iowa. Iowa State University. Extension, Ames Publ. Pm-1688 (Rev.).
Schollenberger, C.J., Simon, R.H., 1945. Determination of exchange capacity and exchangeable bases in soils-ammoniumacetate method. Soil Sci 59, 13-24.

Scott, B.J., Fleming, M.R., Conyers, M.K., Chan, K.Y., Knight, P.G., 2003. Lime improves emergence of canola on an acidic, hardsetting soil. Aust. J. Exp. Agric. 43, 155-161.

Tarkalson, D.D., Hergert, G.W., Cassman, K.G., 2006. Long-term effects of tillage on soil chemical properties and grain yields of dryland winter wheat-sorghum/ corn-fallow rotation in the Great Plains. Agron. J. 98, 26-33.

Thomas, G.W., 1982. Exchangeable cations, In: Page, A.L., Miller, R.H., Keeney, D.R. (Eds.), Methods of Soil Analysis: Part 2. Chemical and Microbiological Properties, Agronomy No. 9. 2nd ed. ASA and SSSA, Madison, WI, pp. 159-165.

Vázquez, M., Terminiello, A., Duhour, M.A., García, M., Guilino, F., 2009. Efecto del encalado sobre propiedades físicas de un suelo de la pradera pampeana: asociación con propiedades químicas. Cienc. Suelo 27, 67-76.

Vázquez, M., 2011. Causas de la acidificación en el ámbito templado argentino, consecuencias y avances para su diagnóstico. In: García, F.O., Correndo, A.A. (Eds.), Simposio Fertilidad 2011. La nutrición de cultivos integrada al sistema de producción. International Plant Nutrition Institute, Rosario, pcia. de Santa Fe 1-10 pp..

Vázquez, M., Terminiello, A., Casciani, A., Millán, G., Gelati, P., García Díaz, J., Kostiria, J., García, M., 2010. Evaluación del efecto de enmiendas básicas sobre la producción de alfalfa (Medicago sativa) y propiedades edáficas en ámbitos templados argentinos. Cienc. Suelo. 28, 141-154.

Vega, C.R.C., Andrade, F.H., Sadras, V.O., 2001. Reproductive partitioning and seed set efficiency in soybean, sunflower and maize. Field Crop Res. 72, 163-175.

Velasco, J.L., Sainz Rozas, H.R., Echeverría, H.E., Barbieri, P.A., 2012. Optimizing fertilizer nitrogen use efficiency by intensively managed spring wheat in humid regions: effect of split application. Can. J. Plant Sci. 92, 847-852.

Walkley, A., Black, I.A., 1934. An examination of the Degtjareff method for determining organic carbon in soils: effect of variations in digestion conditions and of inorganic soil constituents. Soil Sci. 63, 251-263. 